Dept. of Anat., Kyoto Prefect. Med. School, Kawaramachi-Hirokoji, Kamikyo-ku, Kyoto (Prof. Dr. H. YAMADA).

\title{
Histological Studies on the Functional Development of the Thyroid Gland of the Chick Embryo.
}

\section{Histochemical Observations.}

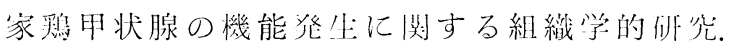

\section{I. 組 織化学的钼 察.}

\section{Hisao FUJITA and Shiro NAGATA 藤旧尚男と亦壮土到。}

(Received October 30, 1961.)

The functional development of various endocrine organs has been one of the most interesting subjects in embryology. Using the thyroid gland of the chick embryo, following problems were examined: 1 . when does the colloid droplet begin to be produced? 2. when does this gland obtain the latent function to produce the colloid droplet? 3. how does the TSH injected affect the early colloid formation of the epithelial cell?

\section{Materials and methods.}

Materials we used in this study were removed from seventy White-Leghorn chick embryos. We made them into 4 groups : group 1 serving as control, group II treated with a single injection of 10 or $25 \mathrm{i}$ u. of the TSH (Pretiron of SHERING) into the yolk sac at 4, 5, 6 or 7 days of incubation, group III with that of 40 1e of $\mathrm{I}^{131} 2-12$ hours before decapitation and group IV with that of the TSH as group II and simultaniously $40 \mu$ of $I^{131}$ as group III. These chick embryos were killed by decapitation at on the $6,7,8,9,10$ and 11 th day of incubation. The group $I$ and II were fixed in BOUIN's solution, embedded in paraffin, cut at $6 \mu$ and stained with periodic-acid-SCHIFF, azan and hematoxylin-eosin. The group III and IV were fixed in alcohol, embedded in paraffin, cut at $6 \mu$ and autoradiographed by súripping method.

\section{Results.}

Normal thyroid glands of the 6, 7 and 8 days old chick embryos were mainly made up of the epithelial cords and loose mesenchyme, and no periodic-acid SCHIFF positive colloid droplet was observed. Though KRAICZICZEK reported that the small colloid spots were found in the epithelial cell of the 8 days old chick embryo, we did not recognize any droplet in normal embryos of 8 days old using both light and electron microscopes,

At 9 days of incubation, in one third of the whole cases, we found a number of small spots of $1-2 \mu$ in diameter stained purple by periodic-acid-SCHIFF method, 


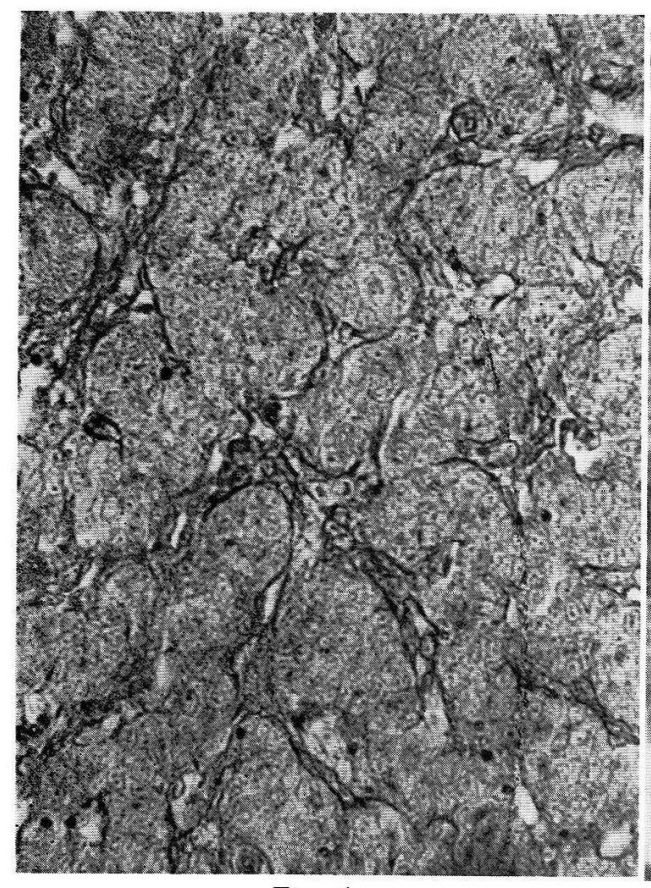

Fig. 1 .

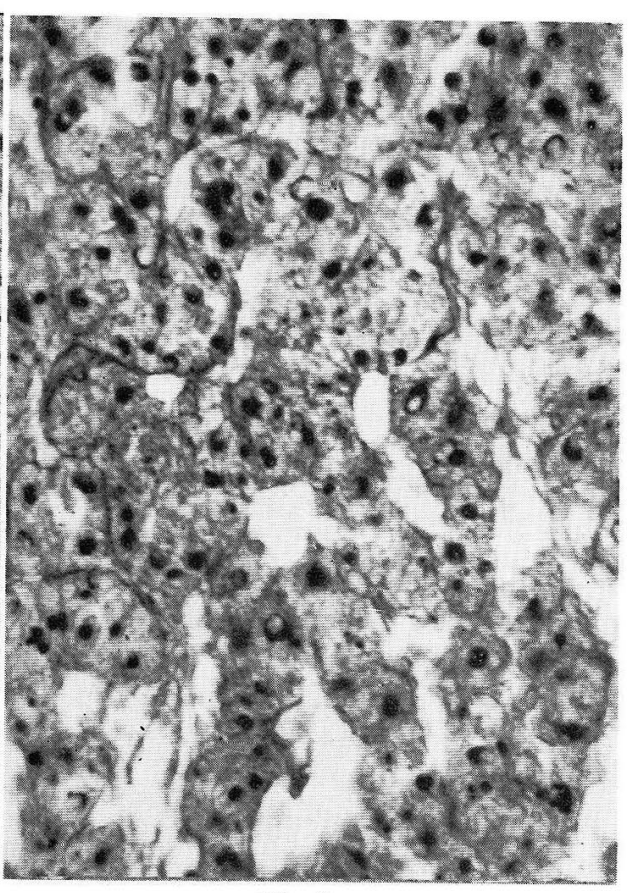

Fig. 2.



Fig. 3 .

Fig. 4. 
distributing throughout the whole epithelial cords, as reported by WOLLMAN and ZWILLING. However, most of 9 day-old embryos lacked of the colloid droplet in this organ. At 10 days of incubation, the droplets were observed in all the cases. They were lying not only between two or a few cells as a simplest colloid follicle, but also in the cytoplasm of a epithelial cell as an intracellular colloid droplet. BRAD. WAY, YOSHIKAWA, HOPKINS and VENZKE reported that the thyroid colloid droplets appeared at 10-11 days of incubation. But the hematoxylin-eosin staining is not always suitable to show clearly the smallest thyroidal colloid spots in the early stage of their formation.

In the case of a single injection of 10 or $25 \mathrm{i}$. u. of TSH at 4, 5, 6 or 7 days of incubation, colloid droplets stained purple by periodic-acid-SCHIFF method appeared distinctly in the thyroid epithelial cords in all 8 days old chick embryos. The diameter of these spots was $1-5 \mu$ and as large as those of normal 10 days old embryo. Before 8 days, even if more than 25 i. u. of TSH was injected at any day, we found no periodic-acid-SCHIFF positive droplet in the thyroid gland.

By autoradiography, the $I^{131}$ uptake of the thyroid gland of the 8 days old embryo was distinct, but at 7 days the radioactivity was too slight to be found out.

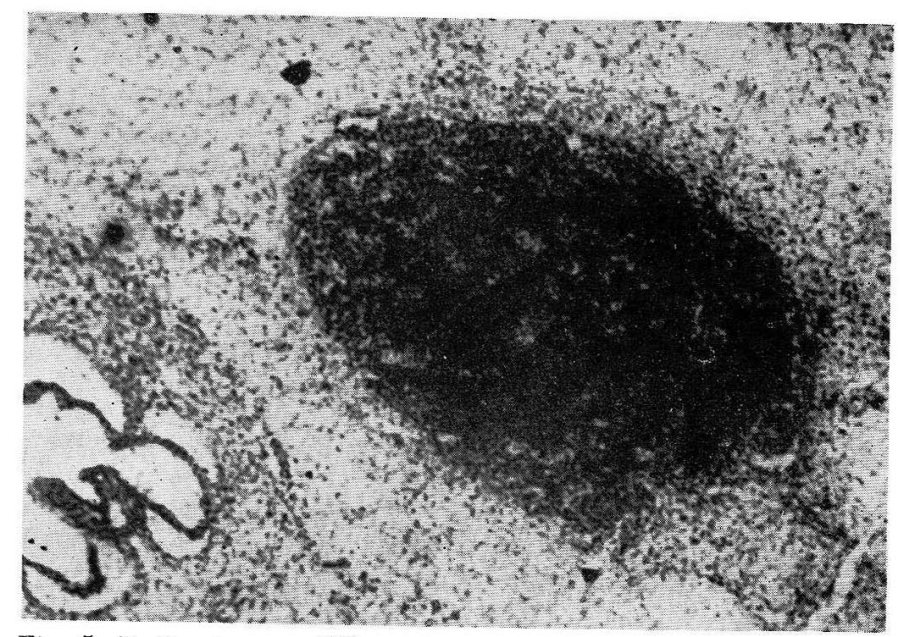

Fig. 5. Radioautogram. I 131 uptake of the normal thyroid gland of a 9 days old chick embryo. Forty $\mu$ c. of $I^{131}$ was injected into the yolk sac 6 hours before decapitation. $\times 120$.

Fig. 1. A normal thyroid gland of a 8 days old chick embryo. Periodic-acid-SCHIFF method. $\times 500$.

Fig. 2. A normal thyroid gland of a 10 days old chick embryo. Periodic-acid-SCHIFF method. $\times 500$.

Fig. 3. A normal thyroid gland of a 11 days old chick embryo. Periodic-acid-SCHIFF method. $\times 500$.

Fig. 4. A thyroid gland of a 8 days old chick cmbryo treated with $10 \mathrm{i}$. u. of TSH at 6 days of incubation. Periodic-acid-SCHIFF method. $\times 500$. 


\section{Summany.}

1. In the normal chick embryo, the thyroidal colloid droplets appear at $9-10$ days of incubation.

2. The thyroid gland obtains the latent function to make a colloid 8 days after the beginning of incubation, but, in this days old embryo the TSH (thyroid-stimulating hormone) content in the blood stream seems not to be sufficient to stimulate the gland.

3. The TSH injected at 4--7 days of incubation stimulates the gland to produce the colloid droplet at 8 days of incubation.

\section{内 容 自 抄.}

白色レグホン種の家瞿艀卵 70 個を用い，4つのグループに分けた。即第 1 の グループはコントロールとし，第 2 のグループには，卵卵満 4, 5, 6, 7 日の何れ かの日に一國 TSH (甲状腺刺激ホルモン) (Shering 製プレチロン) 10-25 単伤を 卵黄囊に注射し，第 3 のグループには動物を殺す 2-12 時閒前に $\mathrm{I}^{131} 40 \mu \mathrm{c}$ 在注 射し，第 4 のグループには上迹の TSH と $I^{131}$ をそれぞれ与えた。乙れらの胎児 は孵卵 6，7，8，9，10 及び11日に断頭し，グループ 1 及び 2 は Bouin 液で间定し てパラフィンで包埋し， $6 \mu$ 薄切，H-E， azan, PAS等の染色在行ない, グループ 3 及び 4 はアルコール闾定, パラフィン包埋後, ストリッピング法によりオート ラジオグラフィーを行なった。

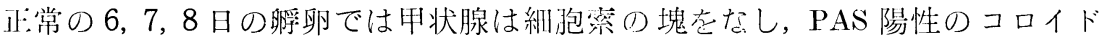
は全く見られない。孵卵 9 日では約 $\frac{1}{3}$ の例に於いて直径 $1-2 \mu$ のAS 陽性の小

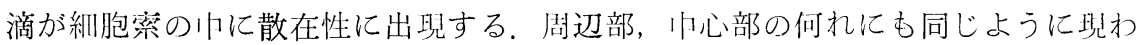
れる。睬卵 4-7 日のよ゙の日かに 1 回 TSH を 10一25単位注射した㘯合には孵卵 8 日で全例に, 甲状腺細胞繁内に直径 $1-5 \mu$ PAS 陽性の小滴が散在性に出見 する。但し孵卵 7 日以前には絶対に鬥われてい。

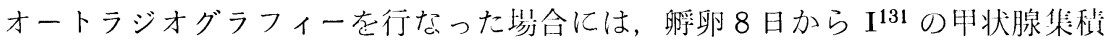
が陽性を示す。それ以前は何之も断定出来ない。TSH 注射のむのでは遙かに大 量のヨードが甲状腺に集まる。

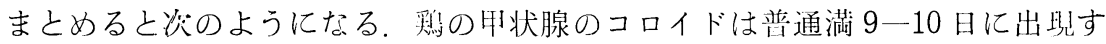
るが，８日から既にコロイド生産能方を有する。ただ体内のTSH 量が少ないた めにコロイド出現がしないのであって，TSH を外部から与えると８日でコロイド が作られることが分かる。但し 7 日以前には甲状腺はコロイド生産能方を有しな い.

\section{References.}

Bradway, W.: Anat. Rec. 42 (1929). P. 157. - Fujita. H. and M. Machino: Expl. 
Cell. Res. 25 (1961). p. 204. - Hopkins, M. L.: J. Morphol. 58 (1935). P. 585. - Kraicziczek, M.: Roux' Arch. Entw. mechan. 148 (1956). S. 518. - Venzke, W. G.: Amer. J. veter. Res. 10 (1949). P. 272. - Wollman, S. H. and E. Zwilling.: Endocrinol. 52 (1953). P. 52. - Yoshikawa, T.: J. Coll. Agricult. 11 (1930). P. 57. 